\title{
Relations between Christians and Muslims in kadi court registers (sicils) and Franciscan chronicles of the $18^{\text {th }}$ century*
}

Dijana Pinjuh

University of Mostar

Faculty of Humanities and Social

Sciences

Sveučilište u Mostaru, Filozofski fakultet

E-mail: dijana.pinjuh@ff.sum.ba

\author{
UDK: 27-789.32"17" \\ 28-67:27]"17" \\ Original scientific article \\ Received: 29 May 2021 \\ Accepted: 29 June 2021
}

\section{Summary}

Based on kadi sicils and Franciscan chronicles, this paper seeks to present a picture of everyday lives of Christians and Muslims during a turbulent period, marked by political turmoil, unrest and general insecurity. Attacks, murders and various other acts of violence were part of everyday life. The ruling class of the time often abused their position and acted beyond their authority, putting additional pressure on the Christian population and further aggravating their social position and security within Eyalet of Bosnia. The efforts of the authorities to protect reaya were only temporarily effective in stopping the violence. The

* A paper on the similar topic was submitted in March 2020 for the scientific conference "Kulturno-historijski tokovi u Bosni (15.-19. stoljeće)" [Cultural and historical flows in Bosnia $\left(15^{\text {th }}-19^{\text {th }}\right.$ century)], which was to be held in Sarajevo on $8^{\text {th }}$ and $9^{\text {th }}$ October, 2020. Due to the COVID-19 pandemic, the conference is postponed to October 2021. 
Dijana Pinjuh - Relations between Christians and Muslims...

perpetrators of violence were mostly indiscriminate concerning their targets as Muslims were also targeted. Despite unfavorable political circumstances, social and religious differences, $\mathrm{Mu}$ slims and Christians privately used to help each other, socialize and cooperate.

Keywords: Christians; Muslims; Christian-Muslim relations; chronicles; sicils, $18^{\text {th }}$ century.

\section{Odnosi kršćana i muslimana u kadijskim sidžilima i franjevačkim ljetopisima 18. stoljeća}

Izvorni znanstveni rad Primljeno: 29. svibnja 2021. Prihvaćeno: 29. lipnja 2021.

\section{Sažetak}

$\mathrm{Na}$ temelju kadijskih sidžila i franjevačkih ljetopisa nastoji se prikazati život kršćana i muslimana u jednom turbulentnom razdoblju obilježenom političkim krizama, nemirima i općom nesigurnosti. Napadi, ubojstva i razna druga nasilja bila su dio životne svakodnevice, a kršćanima je položaj dodatno otežavao pritisak vladajućih slojeva, koji su često zlorabili svoj položaj i djelovali izvan okvira svojih ovlasti. Pokušaji vlasti da zaštite raju od nasilja samo su privremeno zaustavljali nasilnike, kojih nije bilo pošteđeno ni muslimansko stanovništvo. Unatoč nepovoljnim političkim okolnostima, društvenim i vjerskim razlikama, muslimani i kršćani pomagali su jedni drugima, zajedno se družili i surađivali.

Ključne riječi: kršćani; muslimani; kršćansko-muslimanski odnosi; ljetopisi; sidžili; 18. stoljeće. 


\section{Introduction}

Interpersonal relationships and ties between Christians and Muslims in religiously diverse environments have been and remain a part of everyday life. There are numerous testaments of members of different religious communities helping each other, socializing, working together and often being connected by marriage, sponsorships and sincere and strong friendships. This way of life is the product of the centuries-old traditions and ties Herzegovinians and Bosnians have been cultivating since the first conversions to Islam took place in the Ottoman period. In the early years after the conquest, many subjects of the Ottoman Empire sought relief from tax levies and other hardships via conversion to Islam. Despite this, the converts' ties with their original Christian families in most cases were not severed. ${ }^{1}$

(Un)written history conceals many examples of Christian-Muslim relations and connections. These relations were often benevolent, but depending on the circumstances, they were also malicious and treacherous. Various examples of Christian-Muslim cooperation, legal-property disputes, joint usage or sale of the land, debts, but also mutual lawsuits, attacks and intolerance can be found in the $17^{\text {th }}$ century sicils. ${ }^{2}$ Despite discriminate behaviour imposed by differences

1 For more on this see: Dijana Pinjuh, "Conversions to Islam in Bosnia and Herzegovina, and the connections between the converts and their Christian families, from the Ottoman Conquest to the End of the Seventeenth Century", in: Povijesni prilozi, 55, Zagreb, 2018., pp. 205-229. The same paper, but with minor corrections was also published in Croatian. "Prijelazi na islam u Bosni i Hercegovini i veze konvertita s njihovom kršćanskom obitelji, od osmanskoga osvajanja do kraja 17. stoljeća", in: Motrišta, 106-107, Mostar, 2019., pp. 68-83. The examples of Ottoman dignitaries from Bosnia and Herzegovina who provided members of their close and extended families to reach high positions, were a clear indicator of the ties and relations between Christians and their islamized relatives. This is best illustrated by the example of Vizier Mehmed Sokollu, under whose auspices the Patriarchate of Peć was renewed in 1557, and his brother Makarije became the patriarch. Other members of the Sokollu family, who had also converted to Islam, reached high positions mainly thanks to the efforts and commitment of their cousin Mehmed Sokollu. See more about him: Радован Самарџић, Мехмед Соколовић [Mehmed Sokollu], Завод за уџбенике, Београд, 2010.

2 Sidžil mostarskog kadije 1632.-1634. [Sicil of the kadi of Mostar], MuHamed A. MujIĆ (ed.)., IKRO Prva književna komuna, Mostar, 1987.; Sidžili mostarskog kadije, fragmenti iz 1044-1207. h. god. / 1635-1793. (regesta) [Sicils of the kadi of Mostar, fragments from 1044-1207, Chr. yr. / 1635-1793 (regesta)], HivziJA Hasandedić (rev.), Arhiv HNK/Ž, Mostar, 2011, pp. 31, 33-34, 47, 50, 55-56, $62,68,69,84-85,86,87$. 
in social status and changes of political circumstances, Christians and Muslims were managing to find ways to cooperate in many diverse fields of life.

The aim of numerous earlier studies was to fully comprehend the relationships and the extent of the influence Christian and Muslim population had over each other. These studies sought to clarify the complexity of such relations from the time of Prophet Muhammad to the present day. ${ }^{3}$ Concerning the study of Christian-Muslim relations during the period of Ottoman rule in Bosnia and Herzegovina (hereinafter: $\mathrm{BiH}$ ) kadi sicils and the $18^{\text {th }}$ century Franciscan chronicles present valuable and interesting sources this paper mostly relies on. ${ }^{4}$

3 Here are just a few of the authors who have dealt with the mentioned topic: Maнmoud Ayoub, "Islam and Christianity between tolerance and acceptance", in: Islam and Christian-Muslim Relations, vol. 2, 2/1991., pp. 171-181; BERT Breiner, "Christian-Muslim relations: Some current themes", in: Islam and Christian-Muslim Relations, vol. 2, 1/1991., pp. 77-94; Amnon Cohen, "The Ottoman approach to Christians and Christianity in sixteenth-century Jerusalem", in: Islam and Christian-Muslim Relations, vol. 7, 2/1996., pp. 205-212; Ismail Albayrak, "The People of the Book in the Qur'ān", in: Islamic Studies, Islamabad, vol. 47, 3/2008, pp. 301-325; CHAD F. EMmetт, "The Siting of Churches and Mosques as an Indicator of Christian-Muslim Relations", in: Islam and Christian-Muslim Relations, vol. 20, 4/2009., pp. 451-476; HAKAN ÇORUH, "Friendship between Muslims and the People of the Book in the Qur'an with special reference to Q 5.51", in: Islam and Christian-Muslim Relations, vol. 23, 4/2012., pp. 505-513; Uriya Shavit, "Can Muslims Befriend Non-Muslims? Debating al-walā' wa-al-barā' (Loyalty and Disavowal) in Theory and Practice", in: Islam and Christian-Muslim Relations, vol. 25, 1/2014., pp. 67-88.

4 We have used four published and seven unpublished sicils. Photocopies of unpublished sicils are in the Archive of Herzegovina-Neretva Canton (hereinafter: Arhiv HNK/Ž) Mostar. Three photocopies are registered in the inventory of Acta turcarum under numbers 23/1121, 23/1124, 23/1125, while the other four photocopies are not numbered. Originals of five photocopies are in the Oriental Institute of Sarajevo and are registered in the Inventory of Official Books under numbers $56,57,58,60,61$. For two photocopies there is no information about the original manuscript. All translations were made by the archivist of the HNK/Ž Arhiv, Hivzija Hasandedić.

The following chronicles were used in this paper: MARIJAN Bogdanović, Ljetopis kreševskog samostana (1765-1817) [Chronicle of the Kreševo Monastery], Ignacije Gavran (trans. and ed.), Synopsis, Sarajevo - Zagreb, 2003.; Bono Benić, Ljetopis sutješkoga samostana [Chronicle of the Sutjeska Monastery], Ignacije Gavran (trans. and ed.), Synopsis, Sarajevo - Zagreb, 2003.; Nikola Lašvanin, Ljetopis [Chronicle], Ignacije Gavran (trans. and ed.), Synopsis, Sarajevo - Zagreb, 2003.; JAKo BALtić, Godišnjak od događaja crkvenih, svjetskih i promine vremena u Bosni 1754-1882 [Yearbook of church 
Although scanty and incomplete, the sources at the disposal provide insight into Christian-Muslim relations, their connections, contemporary views on life and the ways the individual of the time struggled for their rights and justice. The information we find in the sicils researched in this paper do not differ from the contents of the court registers of other countries, formerly parts of the Ottoman Empire. The verification of this claim can be found in the examples from the $17^{\text {th }}$ century sicils of Sofia, researched by Rossitsa Gradeva ${ }^{5}$ and the $18^{\text {th }}$ century sicils researched by Kemal Çiçek. ${ }^{6}$ Due to the diversity and abundance of data in the sources researched in this paper, the research has been limited to those events that speak of Christian-Muslim relationships in either negative or positive context, while the information on the relations of Ottoman authorities towards the Franciscans and their struggle to pay (illegal) taxes, numerous fines and permissions required for the construction or reconstruction of monasteries and churches, for the most part, were omitted. The reason for limiting the research is the abundance of examples contained within the chronicles, as well as the complexity of the topic itself. Therefore, it is rather difficult to cover all the examples in a single study. The chroniclers' records and their testimonies deserve a separate study in which all the difficulties Franciscans had struggled with, throughout centuries of Ottoman rule, would be elaborated in detail.

and world events and changes of time in Bosnia], Andrija Zirdum (trans. and ed.), Synopsis, Sarajevo - Zagreb, 2003. On the historical significance of the Franciscan chronicles and the analysis of the first two chronicles, see: VJERAN KurSAR, „Živjeti krstjanski pod turskim gospodstvom: Osmansko Carstvo u djelima bosanskih franjevaca 18. stoljeća" [Living in Christian way under Turkish rule: The Ottoman Empire in the works of Bosnian Franciscans of the $18^{\text {th }}$ century], in: Dolores GrmaČa, Marijana Horvat And Marko Karamatić (eds.), Zbornik radova sa znanstvenog skupa Matija Divković $i$ kultura pisane riječi, II., Zaklada Kulturno-povijesni institut Bosne Srebrene Hrvatska sveučilišna naklada, Sarajevo - Zagreb, 2017., pp. 449-475.

5 Rossitsa Gradeva, "Orthodox Christians in the Kadi Courts: The Practice of the Sofia Sheriat Court, Seventeenth Century", in: Islamic Law and Society, vol. 4, 1/1997., pp. 37-69.

6 Kemal ÇıçEK, "Living together: Muslim-Christian relations in eighteenthcentury Cyprus as reflected by the Sharīa Court records", in: Islam and Christian-Muslim Relations, vol. 4, 1/1993., pp. 36-64. The position of zimmis of Damascus in the $18^{\text {th }}$ and $19^{\text {th }}$ century was elaborated based on the information available in sicils. Najwa Al-QATtan, "Dhimmis in the Muslim Court: Legal Autonomy and Religious Discrimination", in: International Journal of Middle East Studies, vol. 31, 3/1999., pp. 429-444. 
The aim of this paper is not to present the history of coexistence - a term popularized by the international community in this area after the end of the war in $\mathrm{BiH}$ in the 1990s, but to present a comprehensive picture of everyday life and relations within the given territory during the given period of time. In order to obtain a comprehensive picture of Christian-Muslim relations, in some instances it was necessary to deviate from the time frame addressed in this study. Therefore, some examples from earlier periods of time had to be included in the research.

\section{About the influence of political circumstances on Christian- Muslim relations}

The Sançak of Bosnia (since 1580 the Eyalet of Bosnia) originally had an important offensive, and later on, defensive role in the military matters of the Ottoman Empire. Bordering European Christendom, the Eyalet of Bosnia had initially served as the staging ground for the Ottoman advances against neighbouring Christian countries. But, after the territorial losses sustained in the wars of the $17^{\text {th }}$ and $18^{\text {th }}$ century, the Eyalet became one of the most protruding and exposed (vulnerable) Ottoman European provinces, playing an important role in preserving the Empire's European borders in the $18^{\text {th }}$ century. The severity of the attitude of the Ottoman authorities towards Christian population depended on the context of general socio-political insecurity and economic crisis. This can be partly attributed to the very position the Empire was in at the time ( $18^{\text {th }}$ century). The state was being eroded by internal unrest and crisis that was deepening, and the provincial governors sought to use their mandate for personal enrichment only. At the same time, powerful locals, mostly tax-holders and government-holders, were committing numerous abuses of power and injustices to the detriment of the reaya. ${ }^{7}$ Therefore, the connections and acquaintances with Muslims were crucial in resolving various disagreements and dangers that were threatening Christian population.

7 According to research by Nedim Filipović, from the end of the $17^{\text {th }}$ century, the term "reaya" began to be used much and more often exclusively for non-Muslim subjects, and this meaning of the term would completely prevail other meanings in the $18^{\text {th }}$ century. Недим Филиповић, "Поглед на османски феудализам (с посебним освртом на аграрне односе)" [An overview of Ottoman feudalism (with special reference to agrarian relations)], in: Годишюак историског друштва Босне и Хериеговине, IV., Сарајево, 1952., p. 115. 
After the peace agreement in Srijemski Karlovci was signed in 1699, a large number of Muslims migrated to the territory of the Eyalet of Bosnia. The territorial loss of Slavonia and Lika incurred Muslim hostility towards Christians. This was especially the case with immigrant Muslim population which was notably hostile towards Christian population. That hostility had serious consequences in everyday life. Muslims and janissaries most often expressed their frustration with the battlefield setbacks by directing violence to Christians and their priests. In several instances, the Chronicle of the Kreševo Monastery mentions that the behaviour of kadis (Sharia judges), janissaries and other Muslims towards Christians was negatively influenced by changes in the political context. ${ }^{8}$

The peace treaty of 1699 did not bring an end to the political tensions on the Venetian-Ottoman border, as the Second Morean War (1714-1718) ensued soon after, and the Ottomans experienced new territorial losses. By the end of the century, the political situation did not change significantly. The Ottoman Empire was continuously facing new perils, which in turn presented constant trials and challenges for the population of Eyalet of Bosnia. Increasing tax burdens, exploitation and tyranny manifested by powerful locals kept worsening the social position of both Christians and Muslims. Some of the oppressed started defecting to haiduks, ${ }^{9}$ while some even started openly protesting and revolting ${ }^{10}$ against tyrannical governing structures. The changing fortunes of war, constant pressure of the governing structures, insecurity and uncertainty negatively influenced Christian-Muslim relations. The extent to which

8 M. Bogdanović, Ljetopis kreševskoga samostana, pp. 113, 117, 119, 123, 141, $155,170,171$. From the very beginnings of Islam, political circumstances have been influencing Muslim and non-Muslim relations. For more information: H. Çoruh, "Friendship between Muslims and the People of the Book...", pp. 506-507. In her research of Christian approach to the Sharia court in Sofia during the $17^{\text {th }}$ century, Rossitsa Gradeva also notices that there was intolerance between Christian and Muslims "although in a latent state, and was easily stirred by an act of defiance or in times of political crisis." R. GRADEvA, "Orthodox Christians in the Kadi Courts...", p. 69.

9 See more in: Dijana Pinjuh, "Hajdučija u Hercegovini u 18. stoljeću" [Brigandage in Herzegovina in the $18^{\text {th }}$ century], in: Hercegovina, 5, Mostar - Zagreb, 2019., pp. 115-140.

10 See more in: Muhamed Hadžijahić, "Bune i ustanak u Bosni sredinom XVIII stoljeća" [Revolts and the uprising in Bosnia in the middle of the $18^{\text {th }}$ century], in: Historijski zbornik, 33-34 (1), Zagreb, 1980. -1981., pp. 99-137. 
political crises affected mood changes towards members of other religious communities is best illustrated by two examples recorded in the Franciscan chronicles. The first was recorded during the Austro-Ottoman conflict near Banja Luka in 1737. In this instance reaya and the Franciscans, especially the guardians of the Fojnica, Sutjeska and Kreševo monasteries, were suspected of collaboration with the Christian army. The main evidence of this "treason" was a statement given by a Vlach that had been captured by the Ottomans near Travnik. The captive apparently stated that the cause of the conflict had been activities of "your reaya and the friars". Even though the outcome of the battle was positive for the Ottomans, due to the slander about the Franciscan involvement in the conflict, i.e. treason, the guardians, as well as all the friars, were to be brought before the pasha. Only by guaranteeing for each other and paying large sums of money, did the Franciscans manage to evade the punishment they were facing. ${ }^{11}$ Another such example was recorded in 1771 during of the Russo-Ottoman war (1768-1774). The conflict had unfavourable development for the Ottomans. In February 1771, three intoxicated Muslims, neighbours of the Kreševo Franciscans, approached the monastery courtyard and demanded to be let in. Then they fired their weapons at the cloister door and stoned the roof. What the chronicler specifically pointed out is that, during his time, such a thing had never happened before. Such incidents had not been expected, especially from Franciscan's close neighbours. The chronicler further commented that, the "Turks, therefore, were getting worse."12

The example above becomes increasingly interesting considering that only a few months earlier, on 8 November 1770, Ahmed Basha Hodžić, a wealthy barber and Kreševo Franciscans' neighbour, invited four Franciscans from the monastery to his son's wedding. Two friars accepted the invitation and attended the lunch, having pre-

11 For more details on this event see: B. Benić, Ljetopis sutješkoga samostana, pp. 137-144. Nikola Lašvanin wrote about the same event. Having heard for the accusation of the captured Vlach, the Travnik Vizier Ali Pasha Hekimoglu, according to Lašvanin, said: "da najpri udrimo s Nimci a kad se vratimo, sve ćemo okrenut pod ma i nabit na kolje što' je muško do sedam godina, al' žensko $u$ ropstvo. [Let's strike at the Germans first, and when we return then, we will settle the score with the people, and impale what all the males up to seven years of age, but and females shall we enslave.]". N. LAšvanin, Ljetopis, p. 209.

12 M. Bogdanović, Ljetopis kreševskoga samostana, p. 171. 
viously sent an appropriate gift for such an occasion (five flasks of brandy). The other two friars, of the four invited, apologized, citing their Advent commitments (the friar's fast begins on 2 November and lasts until Christmas). The barber and emin also requested four horses from the monastery in order to transport the bride from Visoko, which were also granted. ${ }^{13}$ It is not known if the Franciscans were truly joyous about the invitation to the wedding, but from what has been recorded, it is seemingly clear that Ahmed Basha's invitation contained no hidden intentions.

Based on the (text) above, it can be concluded that the anti-Christian mood primarily depended on the personality types of the bearers of the attacks and the initiators of violence and not the entire $\mathrm{Mu}$ slim population. However, the influence of a negative socio-political atmosphere occasionally inspired entire Muslim communities to publicly disrespect or disapprove Christian monuments and insignia. The local Muslims in Fojnica, especially the kadi, complained in 1746, that their horses were afraid of the cross at night on Ruknovac (today Rupnovac). The cross had been placed near the road to the grave of the late friar Mijo Kumić few years earlier. For this reason, the Franciscans of Fojnica had to pay 1,100 guruş. ${ }^{14}$

A cross was also a reason Franciscans had to pay a fine in 1781. This time money was extorted from the friars of Kreševo monastery, only under another pretext. Allegedly the cross in front of the Kreševo church was "zarar", i.e. had detrimental effect "on Muhammad's faith", the Franciscans were asked to remove it. As the friars did not possess a written permission to remove the cross (and without permission nothing could be built or removed), it was decided that the guardian and mahalle başı (elder of the mahala or a village) discuss the matter with local Muslims in front of the mosque. When it was confirmed that the local Muslims supported the removal of the cross, it was agreed that two local Muslims do it secretly, for a fee (each received a guruş). Since the kadi could no longer fine the Franciscans because of the cross in question, he demanded 350 guruş for a lawsu-

13 Ibid., p. 153.

14 B. Benić, Ljetopis sutješkoga samostana, pp. 169-170. About the same writes: N. LAšvanin Ljetopis, pp. 223-224. One of those who were removing the cross, certain Muhamed Čelebić, became seriously ill and before his death he sought forgiveness from the friars because he had supported the kadi's lawsuit against the cross. N. Lašvanin, Ljetopis, p. 231. 
it. The guardian had no such money and was therefore imprisoned. For his release, the guardian had to pay 400 guruş. ${ }^{15}$

It is possible that the preaching of religious fanatics was creating tense atmosphere among Catholics and Muslims alike. After the fire of 1765 , in which the monastery and church of Kreševo were destroyed, the Franciscans had to put in serious effort and display serious diplomatic skill in order to get permission from the authorities to rebuild. ${ }^{16}$ Throughout that struggle, there were those who were willing to stand up for the friars. Still, "more respectable Turks" had to be rewarded (bribed) with money, in order to make them "friendlier and more sympathetic"17 to the cause. The friars also had to bribe the individuals working against their cause. Sarajevo Vaiz (preacher) Emir, was ardently opposing the construction of the monastery and the church, beginning each of his sermons with a call: "Whoever is of Muhammad's faith, go and destroy the scum in Kreševo! [Tko je vjere Muhamedove, ajde ona govna u Kreševu razorit!]."18 Perhaps it was under the influence of such thinking, that few years later (1768), mulla (kadi of higher rank) of Sarajevo threatened to demolish Kreševo monastery, because it had allegedly been built without a ferman (imperial edict). The main goal of that threat was to extort the money. Only after 300 guruş were extorted from the Franciscans, did the mulla confirm all the documents. He strictly threatened the friars not to spread the word about the extortion. ${ }^{19}$

15 M. Bogdanović, Ljetopis kreševskoga samostana, pp. 207-208. Benić also wrote about the same event: B. BEnIĆ, Ljetopis sutješkoga samostana, p. 319.

16 About the efforts of the Franciscans to obtain permission to build a monastery, about the amounts of money they had to pay for it, about inspections before and after construction, and about the construction itself, see: M. BoGDANOvić, Ljetopis kreševskoga samostana, pp. 54-58, 63-65, 67-68, 71, 78-95.

17 Ibid., p. 57.

18 M. Bogdanović, Ljetopis kreševskoga samostana, p. 89. The mentioned vaiz came from Amasya to Sarajevo in 1760, where he became the fanatic leader. He was cursing not only the members of the ulema (kadis, dervishes, pashas) but also the shaykh al-Islam (the person with the highest level of knowledge and authority in religious matters) himself. He was the muderris of the Sarajevo madrasa on Bendbasha and became "the leader of the Puritan Muslim fundamentalist movement" in Sarajevo. His preaching was causing tensions even among the Muslim inhabitants of Sarajevo. V. KurSAR, „Živjeti krstjanski...", p. 454.

19 M. Bogdanović, Ljetopis kreševskoga samostana, p. 115; J. BALtić, Godišnjak od dogadaja..., pp. 53-54. In the list of mullahs in Bosnia for 1768, Es-Sejjid Ali Efendi is mentioned as the mulla of Sarajevo. Azra Gadžo-Kasumović, 
As ardently as Vaiz Emir was preaching against Christians, so much the kadis, in their ingenuity for profit, were managing to exploit and damage them financially. Perhaps the vaiz would have been more successful in his intention, had he used the mulla's tactics. Some representatives of the Ottoman authority were so greedy, that they even did not hesitate to fine their Muslim subjects (illegally). A ferman was issued in November 1768, to confiscate weapons from Christians, and in January of the following year, 35 guruş were extorted from the Franciscans, all under the pretext of illegal weapons possession, 400 guruş were extorted from other Christians and Muslims, from the village of Bukva, near Kreševo. The Muslims were accused of buying weapons from Christians. ${ }^{20}$

In the examples of violence that will be discussed further in this text, it is difficult for to ascertain whether and to what extent, was the violence result of political change. The looming danger of war was constantly being felt because of military movements and rumours that were coming from the battlefield. The general social and economic crisis, during the $18^{\text {th }}$ century, were seriously impacting behaviour of Muslims towards Christians, and vice versa.

The $18^{\text {th }}$ century was a difficult time period for both Christians and Muslims, but the Christians were in more difficult situation. They

"Mulla u Bosanskom ejaletu" [Mulla in the Eyalet of Bosnia], in: Anali GHB, 27-28, Sarajevo, 2008., p. 61. About the function and position of the mulla in the Eyalet of Bosnia see: Ibid., pp. 5-67.

20 M. Bogdanović, Ljetopis kreševskoga samostana, pp. 113, 117. A copy of the ferman on the confiscation of weapons from rayah can be found in: Sidžil nevesinjskog kadije 1767.-1775. godine (regesta) [Sicil of the Nevesinje kadi 1767-1775 year (regesta)], Hivzija Hasandedić (rev.), Arhiv HNK/Ž, Mostar, 2009, pp. 54, 58 and Sidžil blagajskog suda, fragmenti iz 1141.-1203. (1729.1789.) [Sicil of the kadi of Blagaj, fragments], sheet 33/b. Shortly after the ferman was issued, the Bosnian Vali, on the $11^{\text {th }}$ of Rajab in 1182 (November 1768) ordered the kadis of the Herzegovinian sancak, captains, aghas, ayans of Vilayet and officials to confiscate all the weapons rayah were hiding in "houses, churches and hiding spots". The weapons were to be sold to the army and the money was to be given to their previous owners. Sidžil mostarskog kadije, fragmenti iz 1179-1182. h. g. / 1765-1769. g. (regesta) [Sicil of the kadi of Mostar, fragments from 1179-1182 chr. year. / 1765-1769 (regesta)], Hivzija HASANDEDIĆ (rev.), IC štamparija Mostar, Mostar, 2014., pp. 62-63; Sidžil nevesinjskog kadije 1767.-1775., p. 57. However, as early as in April 1769, a ferman arrived allowing reaya to bear arms again, for which Fojnica and Kreševo gave 60 guruş. M. BogdANović, Ljetopis kreševskog samostana, pp. 123, 124. 
Dijana Pinjuh - Relations between Christians and Muslims...

were exposed to constant pressure, persecution and violence and had to be vigilant over their own actions. Only sometimes would they have the protection of a Muslim, whether that was an individual from the governing structures, social elite, or regular folk.

\section{Mutual Christian-Muslim attacks, assassinations and accu- sations}

Neighbour relationships were determined by circumstances, common interests, social status and individual personality. Envy, jealousy and the desire to own someone else's property were as present during the Ottoman period as during any other. Display of such behaviours often culminated in serious consequences. An attack, that took place in Blagaj kadiluk area at the end of the $17^{\text {th }}$ century $\left(26^{\text {th }}\right.$ Jumada II 1111 or December 1699) illustrates this well. An unnamed criminal, from the village of Donje Suhaje, attacked his neighbour Ilija, put him in bukagi (chains), and tried to rape his wife Manda, injuring her in the process. The Bosnian Vali (governor) ordered the Blagaj kadi to find and arrest the perpetrator, and in case locals protected him, they were to be brought to the Divan as well. ${ }^{21}$ The document does not state the name of the perpetrator. Since Ilija (the victim) ended up in chains, it is highly likely that the perpetrator was a Muslim neighbour. Christians, at that time, were not in a position to put anyone in chains; this privilege was reserved only for Muslim subjects, that is, those who were in one of the military services.

Unlike Ilija's attacker, the names of the Muslims who were conducting criminal activities in the villages of the Blagaj kadiluk were listed. The buyuruldu (an order) of the Herzegovinian Vali Abu Bećir Pasha, issued on $14^{\text {th }}$ Rebia II in 1145 (beginning of October 1732) lists the following criminals: Ahmet Girović (Giroogli), Ismail Kolaković, Omer Ćupina, Mehmed Ejubagić (Ejubogli) and Daje. The individuals listed were suspected of jointly conducting armed attacks against "the slaves of God and poor reaya" in the Blagaj kadiluk. They were apparently assaulting their victims in their homes, stealing their belongings and committing other acts of violence. Because of the

21 Sidžil blagajskog kadije 1697.-1793., sheet 14/a. About the documents issued by the Bosnian Vali see: Azra Gadžo-Kasumović, "Funkcija osmanskog valije u Bosanskom ejaletu i dokumenti koje je izdavao" [The function of the Ottoman governor (vali) in the Eyalet of Bosnia and the documents he issued], in: Anali GHB, 33, Sarajevo, 2012., pp. 5-58. 
attacks, reaya sent an rrzuhal $^{22}$ (petition, complaint) in which they complained about the attackers. ${ }^{23}$ Since the composition of the population in almost all Herzegovinian villages was mixed, both Christians and Muslims were victims of the mentioned attacks.

Christians were generally being targeted by attackers regardless of the valuables they were carrying or the place they were in: their home, village or on a trip. In the mid $18^{\text {th }}$ century, an attack on the daughter of the çiftçi Ilija Vukosav from Vijonica was recorded. In the document the girl's name was translated as Felemia, but it is more likely that her name was Filomena. She was attacked by Ibrahim Martinoglu, Ibrahim Čolić, Hasan Bajgorić and Ismail Osmanoglu while taking her sheep from Vijonica to Stolac. The attackers stole her bag, which she had carried with a belt (the year is not explicitly stated, but it is probably 1756). ${ }^{24}$

Felemija/Filomena was lucky not to be injured, for not all the attacks went without serious consequences. In the Blagaj kadi sicil, a case of zimmi named Boško from Ilići from the Mostar kadiluk was recorded. This individual dispatched an arzuhal to the Bosnian Divan for the murder of his son Petar in 1177 (1763). According to Boško, Petar was on his way to the village of Miljkovići, when he was invited by certain Omer Šantić to his house. Omer and his companions, first robbed and then killed Petar. Apart from the aforementioned Šantić, Salih Salčinović, Alija Ožegović and Mihajlo Golić from Miljkovići, and a certain Škorić, Ilija Krešić and Tadija from Ilići took part in the crime. ${ }^{25}$ This was probably a premediated crime, as the three of the accomplices were said to be from Ilići, as was their victim. It is obvious that they were familiar with Petar's movement, and devised a plan to rob him.

Not all the attacks were motivated by greed, though, just as the Christians were not always the victims. Kadi Salih of Blagaj informed

22 For more about arzuhal, arz and other documents see: Azra KasumovićGADžo, "Diplomatički dokumenti: arzuhali, mahzari, arzovi, ilami i sahha bujuruldije - molbe, žalbe, kolektivne predstavke, prijedlozi, izvještaji i sahhabujuruldije" [Diplomatic documents: arzuhals, mahzars, arzes, ilams and short sahha-buyruldis - Complaints, complaints, collective applications, proposals, reports and sahha-buyruldis], in: Anali GHB, 31, Sarajevo, 2010., pp. 5-44.

23 Sidžil blagajskog kadije 1697.-1793., sheet 6/b.

24 Sidžil blagajskog kadije 1698.-1779., sheet 35/a.

25 Sidžil mostarskog kadije, fragmenti iz 1179-1182. h. g. / 1765-1769., p. 82. 
the Bosnian Vali on the $13^{\text {th }}$ of Dhu al-Hijjah in 1178 (June 1765) about an attack on an underage Muslim girl. According to the girl's brother, Ibrahim, son of Danijal from Kamena, Alija sipahi Žuljević and Stjepan from Kamena beat his sister while she was watching over her cattle. When Ibrahim tried to protect her, Stjepan shot him wounding him in the leg. The culprits were summoned to the court several times, but remained illusive, so the kadi begged that the accused be brought and punished as an example with mubaşır (state envoy) intervention. ${ }^{26}$ None of these events are further mentioned in the sources and we do not know whether the perpetrators were adequately punished. It is clear though, from the examples above, that Christians and Muslims acted together in many spheres of life, even when it comes to various misdeeds.

Another attack, in which the neighbours played a major role, took place in 1767. Hafiz Mehmed, the kadi of Mostar, sent an arz (submission) to the Bosnian Vali on $15^{\text {th }}$ Rebia I 1181 (August 1767) reporting an attack on Lovro Sučić, son of Ivan from Biletići. Lovro stated in the court, that the villagers Durakovići: Osman, Omer and Ahmed, ambushed him as he was walking from his house towards the threshing floor (a place for threshing grain). They attacked him with stones and knocked three of his teeth out. Although the attackers were summoned to court several times, they did fail to appear, so mubaşır was ordered to bring them in, as they were to face punishment for the committed act. ${ }^{27}$ Lovro did not state the reasons for the attack, so why the Duraković clan decided to use him for target practice and ruin his aesthetic appearance, remains a question. Whether an insult, old grudge or revenge were the cause of the attack, or the victim (Lovro) simply happened to be in the wrong place at the wrong time, an answer to the question of the cause of the attack still remains to be found in the sources.

The case of the violence that was recorded in the sicil of the Mostar kadi on $16^{\text {th }}$ Zilkade 1181 (April 1768) is much clearer. In the village of Rotimlja, a gang from Mostar consisting from: Omer, his brother Mahmud, Mustafa kethluda and Abdulah Komarić, attacked several Christians severely wounding one of the victims (Ljubiša Šarenac). The cause of the attack was not explicitly stated in the sources, but the attack followed after the Christians saw the mentioned robbers in

26 Sidžil blagajskog suda, fragmenti iz 1141.-11203. (1729.-1789.), sheet 12/a.

27 Sidžil mostarskog kadije, fragmenti iz 1179-1182. h. g. / 1765-1769., p. 97. 
the inn in which they were about to have a drink. Seeing the gang in the inn, the Christians retreated back to their companions, who were waiting for them near their horses. The case was recorded by Omer, the acting kadi of Stolac, and the testimony was given by Ljubiša Šarenac's brother, Andrija. ${ }^{28}$ From what the aforementioned kadi noted, it seems to be clear that the Christians were victims of a wanton assault, for the records contain no statement that the bandits robbed their victims or extorted anything from them. The very fact that the witness called the perpetrators "bandits" without hesitation, suggests that perpetrators had a history of similar misdeeds. Another recorded attack on Christians is the case of certain Mića against Mehmed sipahi Begovac. Mića sued Begovac for illegally attacking and beating him in a mill located in Tučepi. The accused Begovac denied the accusation, but refused to swear to the veracity of his claim. ${ }^{29}$ Mića was given a single day to prove that the assault had happened. But the assault presumably took place without witnesses, therefore, the plaintiff could not expect a punishment for the accused. Considering the fact that the accused Mehmed refused to swear on the veracity of his statement, it can reasonably be suspected that he committed the crime indeed.

Concerning Christian attacks on Muslims, plaintiffs most often were not capable of proving that the attacks had happened. In one of the sicils, information can be found that certain Husein Plako sued Luka Bulgur for assaulting him (illegally). ${ }^{30}$ However, no other details about this event can be found. The kadi recorded no statement of the accused Luka, admitting or denying the attack. Husein, though, was probably asked to provide evidence for his case. The case of Sulejman Telarević was somewhat more serious. Sulejman sued Luka Strvina and his brother for an insult, murder intent, and damage to his han (inn) door (allegedly, the accused drove his cattle through the door) and destruction of proceedings. Luka denied all charges and swore to the truth of his words. The plaintiff was given three days to prove claims about cattle in the han and the damage to the door. ${ }^{31}$

There were more Christian-Muslim conflicts (incidents) resulting in injuries or deaths than it can be assumed from the given exam-

28 Ibid., p. 117.

29 Sidžil nevesinjskog kadije 1767.-1775., p. 44.

30 Ibid., p. 13.

31 Ibid., p. 32. 
ples, but it is not possible to ascertain who attacked/killed whom and why. ${ }^{32}$ The sources record that more Christians were murdered by Muslims, Muslims being suspected of perpetrating than vice versa, but apart from basic information about the participants in these events, no other details of these events are available. ${ }^{33}$ The motivation for these crimes in the majority of cases was not recorded.

The crimes could have been committed out of revenge, hatred, greed - or none of the reasons listed. Sometimes the reason was not required. This is best illustrated with an example of a murder that occurred on 14 June 1770. One of the Herzegovinian shepherds from the Brotnjo parish was killed by two intoxicated Sarajevo janissaries, when he was passing by the village of Lisovanj (today unknown, op. cit.). Shepherds from Herzegovina were bringing sheep to the Kreše-

32 We have not analysed in detail the examples in which the attackers or murderers of Christians and Muslims remained unknown, as well as the cases in which a Christian attacks or kills another Christian or a Muslim attacks or kills another Muslim. For more on such cases see: Sidžil blagajskog suda, fragmenti iz 1141.-1203. (1729.-1789.), sheets 10/b, 38/b, 49/b, 52/b, 60/a; Sidžil blagajskog kadije, fragmenti 1113.-1212. (1702.-1798.), sheets 5/a, 11/a, 36/b, 46/a, 53/b; Sidžil nevesinjskog kadije 1767.-1775., p. 69; Sidžil blagajskog kadije, fragmenti iz 1173.-1250. (1760.-1835.), sheets 2/b, 35/a, 59/b, 63/a, 66/a, 83/b, 87/a, 97/a; Sidžil blagajskog kadije 1697.-1793., sheet 41/a; Sidžil blagajskog suda, fragmenti iz 1183.-1201. (1769.-1787.), sheets 1/b, 11/b, 25/a; Sidžil blagajskog suda, fragmenti iz 1170.-1237. (1757.-1822.), sheet 33/b. Franciscan chronicles also bring news about the quarrels between Christians.

33 Tripko Humković from Bijeljina 1st. Rebia II 1182 (August 1768) stated in court that his son Simo was found dead, and he suspected that the murderer was Osman Demirović from Stolac; Vuko Humković states in the court that his son Pavao was killed with knife by Alija, the son of Mustafa-basha, while he was going to the mill. Sidžil nevesinjskog kadije 1767.-1775., pp. 61, 70. On $11^{\text {th }}$ Rebia II 1182 (August 1768) Risto, Pilip and another unnamed Christian were found murdered, and one of them was killed by a certain Husseinbeg. Sidžil blagajskog suda, fragmenti iz 1141.-11203. (1729.-1789.), sheet 88/a. Mehmed and his son Ibrahim killed unnamed Christian in Dragićina. Sidžil blagajskog suda, fragmenti iz 1170.-1237. (1757.-1822.), sheet 33/b. In 1768 Merjema was killed and, according to her husband Ismail, Dragić Turubaković mortally wounded her while shooting through a window. Sidžil nevesinjskog kadije 1767.-1775., p. 72. On 25 November 1771, the parish priest Andrija Čavlina was killed in Vodičevo by a "Turk" whom for the chronicler states that he was a "very wicked robber". B. Benić, Ljetopis sutješkoga samostana, p. 269. The parish priest of Volar, Tadija Tomić, was killed near Prijedor with two bullets in the head "by an infidel". J. BALtić, Godišnjak od događaja..., p. 94. 
vo monastery, and the chronicler does not fail to state that the janissaries shot the young man for no apparent reason. ${ }^{34}$

The case of the zimmi Marko, from the village of Krupac in the kadiluk of Sarajevo, should also be mentioned. From the buyuruldu issued on the $19^{\text {th }}$ of Shawwal in 1189 (December 1775), we learn that Marko travelled from Mostar to the kadiluk of Foča accompanied by Alija and Hasan Žuljević and zimmi Čabrilo. At Slatina (a settlement in the municipality of Foča, op. cit.), Marko was killed by his fellow travellers. ${ }^{35}$ Apart from the order to find the culprits and bring them to the Bosnian Divan, buyuruldu does not contain a hint of possible motivation for the murder. Since the murdered man was a zimmi, a poor man who probably possessed no values anyone could benefit from, it can be assumed that a quarrel among the fellow travellers had tragic consequences for Marko.

Marko's case was not the only journey with tragic consequences. Given the insecure times and dangers of bandit attacks, as well as the treacherous companies of men that used to travel together, journeys presented a great risk, being utterly unpredictable. Many travellers have never arrived at their destination. One such case was that of Jovan Kovačević from Mostar, who was believed missing in 1205 (1790). Jovan went missing between the villages of Kokorina, Kamena and Rabina, and the authorities ordered the inhabitants of the mentioned villages to investigate and determine what had happened. The order was carried out and after few months, Jovan's fate was finally known. He was beaten and killed, on his way to Nevesinje, by Osman Gološ and Ćatić Salih from the village of Žulj, in the Blagaj kadiluk. Jovan's brother addressed the authorities on behalf of the family with a request that accused be found and brought before the Sharia court. To conduct the lawsuit they took 200 guruş from an ayan and certain Ibrahim Effendi. ${ }^{36}$

Even when the perpetrators of a particular crime were known and brought to justice, occasionally the innocent, in the following case the Franciscans, suffered the consequences. While an unnamed kadi and serdar were sleeping in Mišo Trgovčićs house on 31 January 1782, the kadi's intoxicated assistant murdered the host (Mišo) with

34 M. Bogdanović, Ljetopis kreševskoga samostana, p. 146.

35 Sidžil blagajskog kadije 1697.-1793., sheet 27/a.

36 Ibid., sheets 60/b, 62/a. 
a knife. The murderer was caught the same night and put in chains, and the kadi begged Mišo's widow, the Franciscans and all the inhabitants not to file a lawsuit and vowed to sort the situation out with the pasha. Despite the pledge and vow, the Franciscans had to pay 150 guruş. ${ }^{37}$

The chronicler recorded another instance for which the friars had to allocate funds in September of the same year. It was a part of the series of such instances. Having obtained the necessary permits, the inhabitants of Sutjeska began to fence the Catholic cemetery. At that time, Ahmet Mustafić, together with other members of Mustafić family from Sutjeska, complained against Franciscans, claiming that his father had sat on one of the graves. Therefore, Ahmed inherited the grave, despite numerous contrasting testaments claiming that the grave was actually Christian. Even so, the Franciscans had to obtain the necessary approvals again, paying various sums to the pasha and his kethluda (deputy). ${ }^{38}$

What makes this case interesting is the fact that Ahmet's father Mustafa was one of the migrants who fled Slavonia in the aftermath of Great Turkish War and moved to Bosnia, i.e. Sutjeska. Perhaps the Mustafić family were looking for some satisfaction for the loss of property in Slavonia by complaining against Franciscans. The complaint against Franciscans might stem from the fact that, after the Ottoman defeat at Vienna in 1683, Fr. Luka Ibrišimović was actively trying to launch an uprising against the Ottomans in Slavonia.

The constant exposure to war further contributed to general insecurity, and everyday life was difficult and uncertain for both Christians and Muslims. Christians, however, were in a much worse position because they were often falsely accused for acts they did not commit and for which they were nevertheless punished. Such examples can be found in the Franciscan chronicles, in which the life injustices and tragedies which Christians and their priests had to endure, are intoed far more than in the sicils. The aim of false accusations or $\mathrm{mu}$ seveds, as recorded in the chronicles, was to take revenge, do harm or to make a monetary gain, depending on the situation. The methods being used by slanderers, were quite ingenious. Thus, in 1741, the people of Visoko persuaded a man named Hasan to accuse the Fran-

37 B. Benić, Ljetopis sutješkoga samostana, pp. 324-325.

38 Ibid., p. 326. 
ciscans of the Sutjeska monastery of having sold him as a child "to kafir"39, that is, to the Christian territory. Several Franciscans were imprisoned because of this slander. The priest of Vareš parish at the time, Fr. Bono Benić, was beaten and also imprisoned. After facing the accuser, who failed to prove his claims before the pasha - it turned out that the suspected Franciscans were children at the time they had allegedly sold Hasan to Christians. The Franciscans were acquitted, with a fine of 500 guruş. ${ }^{40}$ The following example was recorded in November 1760. Again were the Franciscans of Sutjeska monastery slandered. This time, they were accused of courting one Sarajevo widow, a bula, when she was entering a church together with Christian women. The Franciscans had to pay 34 guruş for this slander, and according to the chronicler, the bula did not even approached the church, but walked with the Christian women alongside the river, near the monastery. ${ }^{41}$ In the same chronicle from 1765 we find an example of another false accusation. This time, the accusation was aimed at Franciscan chaplains. According to the chronicler, the kadi of Jajce named Kršlak, was the hasum (enemy) of the Jajce and Dobretić chaplains, and wanted to harm them. He therefore stated that the corpse of a Christian pilgrim "fell at the Mass [fell at the church]", even though the murder took place outside of Jajce. An unnamed Christian quarrelled with his fellow pilgrims during a pilgrimage to Jajce; they killed him before they reached their destination and then they fled. Because of the kadi's slander, the mubaşır imprisoned three friars in Jajce, taking 1000 guruş from them. ${ }^{42}$ Residents on whose territory the crime took place had to pay blood money, i.e. compensation for the murder. In order to avoid payment, the inhabitants of village where the murder took place transferred the dead body to the area of the neighbouring village. It seems that similar tactics were used by kadis against the individuals they did not like.

False accusations also led to tragic events. Certain individual named Sinan was found murdered near Fojnica in 1781. The Christians

39 Kaur or $c^{\prime}(k)$ afir - derogatory term used by Muslims to designate non-muslims or Christians. Abdulah ŠKaljić, Turcizmi u srpskohrvatskom jeziku [Turkisms in the Serbo-Croatian language], Svjetlost, Sarajevo, 1966., p. 401.

40 B. Benić, Ljetopis sutješkoga samostana, pp. 151-156.

41 Ibid., p. 217.

42 Ibid, p. 236. 
who were transporting wine from Herzegovina at the time of the murder near the crime scene, were falsely accused of Sinan's death and imprisoned. The day after the detention, the defendants were publicly beaten and send before vizier in Travnik. Among them, witnesses who falsely accused them were sent before vizier, but they fled shortly after arriving in Travnik. Serdar Mustafa Agha Svrzikapić from Fojnica recognized former janissaries who were expelled from the janissary ranks due to the bad behavior among witnesses. However, the damage had already been done: one of the wrongly accused was hanged, while the others later succumbed to their injuries, consequences of beatings. ${ }^{43}$ Even though the authorities did realize that an innocent man had been executed, and the other innocent Christians had died as the consequence of imprisonment and beatings, the realization itself did not prevent further injustice and violence against Christians.

Sources also record lawsuits by Christians and Muslims regarding the illicit appropriation of livestock, which is not surprising at all. The loss of livestock had terrible consequences, because it was the livestock which played a highly important role in feeding the families. Therefore, the lawsuits of Christians and Muslims that can be found in the sources should be viewed in this context. In one of the sicils issued on the $17^{\text {th }}$ of Dhu al-hijjah in 1182 (April 1769), it was recorded that certain Petar appropriated two huts which he had received as amanet or inheritance. That also meant Petar had been given the huts for safekeeping by Ali Basha Kurt from Mostar. When Ali Basha asked for the huts to be returned to him, Petar refused, asking Ali Basha to prove that the huts were his. After the latter brought witnesses, Peter fled the courtroom and did not respond to judicial summons any longer. As there was no other way to resolve the dispute, it was requested that the mubaşır bring Petar to the Bosnian Divan. ${ }^{44}$ The importance of livestock is visible from the example of Salih Basha Malkadaoğlum, who sued two Christians stating that they took a mare from him without asking permission, loaded it and took it to Zalom. One of the defendants admitted committing the crime ${ }^{45}$ Kadi did not record the punishment he had imposed for the committed act, but given the confession and the fact that no damage

43 J. BALtić, Godišnjak od događaja..., pp. 88-89.

44 Sidžil mostarskog kadije, fragmenti 1179-1182. h. g. / 1765-1769., pp. 42-43.

45 Sidžil nevesinjskog kadije 1767.-1775., p. 14. 
was caused by the theft, it can be assumed that the perpetrators were not severely punished.

Muslims were not strangers to the appropriation of cattle either. They were repeatedly cited as the culprits responsible for the damage done to Christians. Zimmi Pero sued Alija, Ismail and Halil Parlata from Rotimlja for stealing six oxen (probably in 1789, the examples of lawsuits given are not dated) and demanded the case be investigated. ${ }^{46}$ Another undated lawsuit, regarding livestock, can be found in the sicil of the Blagaj Court. Pavle, son of $\mathrm{Ma}[\mathrm{r}]$ tin and Grgur, son of Marko from Jasoč, filed a complaint against two villagers: Salih, son of Mehmed and Mustafa, son of Ismail, for putting 5-6 of their cattle (oxen) behind the lock. When the plaintiffs demanded their cattle be free, the culprits attacked them with $\operatorname{soh}(v) a$ (a piece of wood that serves as a prop) and injured them. As the Christians could not prove their claims, the case was dismissed. ${ }^{47}$ It is interesting that a certain Jašar, the son of Omer, the captain of Počitelj fortress, also complained about the mentioned Salih and Mustafa, and went on to sue them. Jašar's accusation stated that, five years earlier, Salih and Mustafa had rented an ox from him, and he wanted it returned. As he could not prove his claims either, this case was dismissed too. ${ }^{48}$ Salih and Mustafa were fortunate because the accusers could not provide evidence of the duo's shady business and therefore they avoided consequences in both cases. From what the kadi recorded, it is clear that Salih and Mustafa would have swindled anyone they could in pursuit of profit.

Cattle was also important to the Franciscans, not only for their nourishment but also for the exploitation of the animal products (dairy products) and hides they sold. The Franciscans were usually procuring the required livestock from their parishioners. The custom after the Feast of the Holy Trinity ( $57^{\text {th }}$ day after Easter), at the time, was to send cattle from Herzegovina parishes ${ }^{49}$ to the monastery of

46 Sidžil blagajskog kadije, fragmenti 1113.-1212. (1702.-1798.), sheet 40/a.

47 Sidžil blagajskog suda, fragmenti iz 1183.-1201. (1769.-1787.), sheet 44/b.

48 Ibid., sheet 44/b.

49 At the beginning of the $17^{\text {th }}$ century, the administration of the province of Bosna Srebrena exempted part of the Herzegovinian parishes from the jurisdiction of the monastery in Živogošće and assigned them to the Kreševo monastery, wishing to provide relief because of large fines and levies. In the $18^{\text {th }}$ century, the Franciscans of Kreševo pasteurized almost the whole of western 
Kreševo. Usually one of the Franciscans would accompany the herd to the monastery, but due to cattle raiding, the herd would never reach the destination in its entirety. About twenty units of cattle and two barrels of wine were seized in 1768. Although the Kreševo guardian had sued the thieves, who had to pay a fine for the theft, he eventually reconciled with them, fearing their revenge. Similar thing happened in 1771, when Fr. Pavao Budimir was returning from Herzegovina with one such herd. On the way to the Kreševo monastery, he was left without 250 head of cattle that were stolen by Muslims, at various locations. Ago Kresojević himself stole hundred head from him. Muslim peasants in Sovići lied that the cattle driven by Fr. Pavao had grazed their meadows and extorted four guruş from him. ${ }^{50}$ In order to return what was stolen from them, the Franciscans complained to Dugalić Bey, but the chronicler did not record whether the friars received back anything from what was requested. Franciscan complaints usually resulted in the payment of various fines or bribes to several parties in order for the disputes to be ruled in their favour.

Lawsuits over the money were also not uncommon, and plaintiffs were Muslims who sued Christians for unpaid debts or previously done work. We cite the case of Selima from Hodbina, who sued Lazar from Dabrica, through representative Ibrahim Hoca, because he did not pay her anything for the four years she had been working for him. The court settlement was reached, and Lazar paid 2,000 akçe to Selima's representative. ${ }^{51}$ Even years after something had happened, some came to court and accused individuals of having damaged them in some way. Salih Basha from Trebinje sued certain Simo Rupar, from Trusina, for having stolen 150 guruş from him, back when he was visiting him as a guest. The accusation was denied by the defendant..$^{52}$ As justified as the lawsuit was, eight years later and without witnesses, the theft was hardly to be proven. Maybe Salih Basha

Herzegovina. Dominik Mandić, Franjevačka Bosna. Razvoj i uprava Bosanske vikarije i provincije 1340.-1735., Hrvatski povijesni institut, Rim, 1968., pp. 209-210; M. Bogdanović, Ljetopis kreševskoga samostana, p. 64, note 4.

50 M. Bogdanović, Ljetopis kreševskoga samostana, pp. 109, 179.

51 Sidžil blagajskog kadije 1728.-1732. godine (regesta) [Sicil of the Blagaj kadi (regesta)], Hivzija Hasandedić (rev.), Islamski kulturni centar, Mostar, 2009., p. 52. In the same sigil, another claim for money-debt was recorded. Husein kethluda sued Đuro because his brother zimmi named Petar took 650 akçe from him. Ibid., p. 14.

52 Sidžil nevesinjskog kadije 1767.-1775., p. 21. 
just wanted disclose who his possible suspect was, even though he had to be aware that would probably not receive his money back.

Quarrels and disputes between Christians were not uncommon and neither were requests for help of the Ottomans. The event recorded in one of the chronicles is just an example of what sorts of means were used to achieve the goal. The guardian of the Kreševo monastery and other Franciscans had a quarrel with two innkeepers, Franjo Nikolić and Andrija Buzić. The innkeepers had been selling wine in front of the church for years. They complained to the janissaries that the Franciscans were endangering their lives. The Franciscans, fearing the janissaries, turned to other Muslims, who in turn calmed the janissaries. ${ }^{53}$ Both sides sought support from the Muslims, only with different intentions. The innkeepers because they wanted to continue selling at the church entrance, despite Franciscan resentment, and the Franciscans wanted to defend themselves from possible violence. Both sides received a positive response to the call for help. Interestingly, the chronicler did not note money being used as means of solving problems.

Christians and Muslims sought justice for the stolen goods, attacks and other violence perpetrated by various attackers and robbers before the kadi. Based on the information available solely in sicils, it is sometimes difficult to assess in whose favor did the kadis rule and how these cases were resolved. The orders were clear. The case was to be investigated, culprits found and punished. Still, the question remains whether and in what way were the orders executed. Due to the fragmentary nature of sources, it has been difficult to get a complete picture in most cases. On the other hand, the Franciscan chronicles provide somewhat more detailed information about individual events. The chronicles were most often recorded by contemporaries who had personal experience with violence and unpleasant situations with the authorities, or were told of the incidents by firsthand sources. Thanks to this, we can learn of events that followed judicial verdicts. The following example is a recording of what happened in Kreševo, in 1768. At the wedding ceremony organized by Pavao Suđerić for two of his sons, the wedding guests were sitting at lunch, when three janissaries showed up and tried to forcefully enter the compound. Though some of the guests asked janissaries for a permission to continue the celebration in peace, one of the janissaries shot and killed Pavle's sister and wounded two other guests.

53 M. Bogdanović, Ljetopis kreševskoga samostana, p. 169. 
The perpetrators were convicted in court and imprisoned, but were soon acquitted and "many innocent people suffered heavy fines." ${ }^{4}$ A similar situation occurred the following year. Fr. Luka Mikulić, a novice scholar was killed by the recruited janissary Nuhan. The killer ended up in chains, but was soon released and allowed to go to Sarajevo to his Delalić Agha. The Franciscans were advised not to pursue justice, because the Muslims of Kreševo would be fined the same way as Christians were. The adviser stated that fines would turn Muslim neighbours against the Christians, or Kreševo monastery would be fined. Although the pasha was ready to punish the murderer justly, the murderer fled Bosnia with the army that was to fight the war against Russia. Upon his return, the murderer walked around freely, without being punished, and even threatened to kill some other Franciscans and laymen who had something against him. ${ }^{55}$ Christians and Muslims were equally exposed to attacks, thefts, murders and raids, but not all the perpetrators seemed to have been treated and punished equally for their misdeeds. Nuhan escaped punishment thanks to being recruited, but even after his return nothing was done to punish him for the murder. Moreover, the killer openly threatened to commit new atrocities.

The punishment of those responsible for the crimes depended mostly on the kadi verdicts, about which the chronicle of the Kreševo monastery provides interesting information. When a new agha, a certain Apeća, arrived in April 1771, he summoned all the heads (chiefs) and told them that "during these eleven months, 120 murders took place in the mullaluk of this mulla (meaning the Sarajevo mulla, op. cit.) and none of the culprits had been punished." ${ }^{56}$ It can only be assumed how many other atrocities went unpunished during that same

54 Ibid., p. 114.

55 Ibid., pp. 120-123, 130. Further in the chronicle, Bogdanović returns to Nuhan and states that he came from Taslidže (today's Pljevlja) to Kreševo - where he remained for several years. According to the chronicler, who heard the story from others, the local Muslims told Nuhan to leave Kreševo and surrounding area because they did not wish him there. This is the reason why he hid like a bandit and threatened to do even greater evil. Nuhan disappeared from Kreševo on 26 June 1772, and the "Turks" who were looking for him threatened to turn the monastery upside down. The Franciscans appeased them with monetary sums. Ibid., pp. 134, 194. Baltić also brings news about the murder of Fr. Luka Mikulić: J. BALtić, Godišnjak od događaja..., p. 54.

56 M. Bogdanović, Ljetopis kreševskoga samostana, p. 175. According to the census of mullahs in Bosnia in Sarajevo, the former Sofia Kadi Ibrahim el-Ki- 
period. Abuses and violence against reaya did not remain unnoticed at the Porte, which led the Sultan Mustafa III (1757-1774) to react in order to protect his subjects from the violence of local powerful people and bashas. ${ }^{57}$ For this purpose, in 1772, Aliaga Kul kethüdası (janissary agha's lieutenat) was sent to Bosnia. He arrived to Bosnia empowered by the sultan himself to protect reaya from the "basha villains". In order to restore the order, Aliaga executed a large number of those who were disturbing the order in Sarajevo. Chronicler Benić even went to nickname Aliaga "Bič božji protiv zlih Turaka [God's scourge against evil Turks]" and pointed out that Aliaga did no harm to Christians. The local Turks were afraid of Aliaga precisely because he would not receive any gifts (was incorruptible). According to the chronicler, Aliaga himself pointed out that he had received more from his master than he needed. ${ }^{58}$ This example is one of the few cases where the Ottoman state had indeed succeeded in protecting its subjects. Even so, a vast number of various documents testifying violence and abuse of all kinds, shows how ineffective such orders were. ${ }^{59}$ After everything would calm down, and the danger would pass, the powerful locals would continue to act as they did before government intervention.

The Ottoman subjects were obliged to provide accommodation, when the military and government representatives were passing

brisi held that position in 1184 (1770), and Tusi's Ismail-effendi in 1185 (1771). A. Gadžo-Kasumović, "Mulla u Bosanskom ejaletu", p. 62.

57 Basha was the title of wealthier citizen or janissary, but also represented a dignitary. A. ŠKALJIĆ, Turcizmi u srpskohrvatskom jeziku, p. 122. For more on the title (b)pasha see: J. Deny, "Pasha", in: The Encyclopaedia of Islam, New edition, vol. VIII., C. E. Bosworth, E. van Donzel, W. P. Heinrichs and G. Leсомте (eds.), E. J. Brill, Leiden, 1995., pp. 279-281.

58 B. Benić, Ljetopis sutješkoga samostana, p. 272; J. BALtić, Godišnjak od dogadaja..., p. 64.

59 Dozens of different documents testifying to violence, abuse and illegal actions, as well as those in which governors and local government officials are ordered to protect their subjects from such actions, have been recorded in the sicils discussed here. Sidžil mostarskog kadije, fragmenti iz 1179-1182. h.g. I 1765-1769., pp. 50, 51, 79, 111-112,115-116, 127-128; Sidžil blagajskog kadije 1728-1732., pp. 17, 32, 33, 56, 57, 58, 65; Sidžil mostarskog kadije, fragmenti iz 1044-1207. h. god. / 1635-1793., pp. 35, 37, 38; Sidžil blagajskog suda, fragmenti iz 1141.-1203. (1729.-1789.), passim; Sidžil blagajskog suda 1697.-1793., sheets 5/a, 28/b, passim; Sidžil blagajskog suda, fragmenti iz 1173.-1250. (1760.-1835.), sheets 11/b, 12/a, 30/b, passim; Sidžil blagajskog kadije 1698.-1779., sheets 
through their residential areas. These uninvited guests often stayed longer than expected, ruthlessly cleaning the food supplies of their hosts, while committing other acts of violence. It seems that such a modus operandi was also practiced by Muslim subjects who took it upon themselves to behave in someone else's house at their own discretion, without any respect for the host. Stolac kadi Ibrahim recorded a complaint made by Mate Bošković and Niko Pudar on the $13^{\text {th }}$ of Jumada in 1204 (end of January or February 1790). Both men were from the village of Crnići in the kadiluk of Stolac. They complained that Selim and Salih Marić, together with Osman Ćatić, all from the village of Jasen, kadiluk of Blagaj, had looted their house and committed other acts of violence after being hosted by them. The victims demanded the perpetrators be punished and their stolen property returned, because they were "poor reaya". ${ }^{60}$ Even though the kadi had ordered verification of responsibility and punishment of culprits according to Sharia law, which meant that the stolen goods were to be returned, it is not possible to determine whether the order was carried out, from the available data. It is difficult to determine the cause of such behaviour, but the possibility that it was prompted by the political circumstances of that time should not be ruled out. At that time, Austro-Ottoman War (1788-1791), also known as the Dubica War was underway. In that war, Bosnian Muslims put up strong resistance against the Christian forces near Dubica. There was no war in Herzegovina, but the population, as in previous conflicts, was obliged to participate in supplying of the army and the construction or fortification of existing fortresses. All of this what impoverished the population further, and made their living even more difficult.

\section{Love is blind. Or maybe not?!}

Life with members of different religions inevitably led to mixed relationships, with expressions of affection, love that was sometimes forbidden and frowned upon. The ties of Muslim men with Christian women were desirable and viewed upon favourably by the Otto-

10/b, 14/b, 15/a, 25/b, 26/a, 35/b; Sidžil blagajskog kadije 1113.-1212. (1702.1798.), sheets 16/a, 31/b, 35/b, 36/b, 50/b; Sidžil blagajskog suda, fragmenti iz 1183.-1201. (1769.-1787.), sheets 4/b, 16/b, 17/a, 32/b, 45/a. A certain number of translated ferments and other documents from the $18^{\text {th }}$ century are published in the chronicle of the Sutjeska Monastery. B. BENIĆ, Ljetopis sutješkoga samostana, pp. 166-168, 219-220, 331-334, 338-340.

60 Sidžil blagajskog kadije 1697.-1793., sheet 48/a. 
man authorities. This was the case because the children born in such marriages were raised in the Islamic spirit, regardless of whether their mothers had converted to Islam or not. However, a Muslim woman's relationship with a Christian was disapproved because-considered an apostasy and every expression of affection, even the smallest one, was punished in some way. In 1111 (1699) one such case was recorded in the sicil of the kadi of Blagaj. Haji Omer, son of Abdulvehab Effendi, sued a Christian named Slavo, son of Vujadin, because he had "pulled" his daughter Aisha when she was walking down the road. As Slavo denied the accusation, and the accuser could not prove his statements, the case was closed. Interestingly, the defendant refused to swear that he did not "pull" Aisha, which was also recorded in the court record. ${ }^{61}$

Why Slavo pulled Aisha will probably never be fully explained, but the possibility that it was some awkward expression of affection for the girl should not be ruled out. ${ }^{62}$ Even though the incident happened on the road, it seems that there were no witnesses who could testify. This in turn leads to the conclusion that Slavo was waiting for the right moment to approach the girl and let her know how he felt about her. Aisha was probably frightened by his reaction, aware that such a relationship would be a source of much trouble for both of them. Such couples had to find different solutions to avoid the condemnation of their loved ones and possible punishment. The consequences that the relationship between a Christian man and a Muslim woman could have, are most vividly illustrated by the event that took place in 1777 in the village of Dražev Dol near Uskoplje. At that time, the chronicles recorded the case of a "Turkish woman", the daughter of an unnamed sipahi from Skoplje (today's Uskoplje), who fell in love with a Dalmatian who was in the service of her father. Together, they fled to Dalmatia. Because of this, all three Catholic monasteries in Bosnia (Sutjeska, Kreševo and Fojnica) had to pay 253 guruş and 80 aspers, and the Christians of Skoplje were fined with 800 guruş. In addition, Skoplje chaplain, Fr. Petar Skalj, was accused of allegedly baptizing the sipahi's daughter and was running the risk of death penalty. Four innocent Christians and one woman were killed be-

61 Ibid., sheet 14/a.

62 In present day $\mathrm{BiH}$, there is a customary belief that a boy who teases or pulls a girl by her hair, or tries to be near her in some other way, actually shows affection for that girl. 
cause of the escape of a Muslim girl with a Christian. The Venetians returned the girl to her father, out of fear of the Ottomans. Chaplain Skalj was rescued by an unnamed friend a "Turk", who warned him to flee or be hanged. ${ }^{63}$ No more details about the fate of the two lovers can be found in the available sources. It is most likely that Slavo and Aisha would end up in the same or a similar situation had the "pull" not ended in the court.

Regardless of how Slavo's act seemed (in)appropriate to us, the case recorded in 1779 was much more serious. Boško Hodić from Glumina sent an arzuhal to the Bosnian Vali in which he stated that $\mathrm{Hu}-$ sein Džemić and his 3 or 4 friends surnamed Karadža, had attacked his hut and huts of other cattle breeders in the place called Čirman (today unknown, op. cit.), where the locals used to take cattle for summer grazing. The perpetrators had kidnapped Boško's daughter, and kept hiding in the mountains for ten days. Husein, the ringleader, wanted to marry the girl. Boško begged the Bosnian Vali to catch and interrogate the accused perpetrators. ${ }^{64}$ It is unknown what happened to the unfortunate girl and Husein, but the way he approached and treated her, even if he wanted to marry her, is not appropriate for any time or nation. The abduction of Christian girls was not uncommon in the Ottoman period. Pavao Lozić, chaplain of Duvno, ended up in a dungeon in 1748 because he had sent his niece, who was abducted by a certain "non-Christian" Hrnjak, to the territory of Venice in order to protect her. The girl had long been engaged and announced marriage to a Christian. She chose to escape rather than live with a Muslim. ${ }^{65}$ In the sicils elaborated in this article no

63 B. Benić, Ljetopis sutješkog samostana, p. 290; M. BogdAnović, Ljetopis kreševskoga samostana, p. 201. The chronicle of the Kreševo monastery states that Mustaj Pasha Skopljak had three Christians and one woman, a mother of two executed Christians executed. The same chronicle states that, after learning about the escape of chaplain Skalj, kaymekam Čengić imprisoned three guardians and threatened to execute them if they did not hand over the mentioned chaplain. The guardians saved themselves from the dungeon after 16 days having paid 900 guruş. M. BoGDANOvić, Ljetopis kreševskoga samostana, p. 201. About the case of a runaway Muslim woman with a Christian, see also: J. BALtić, Godišnjak od događaja..., p. 77.

64 Sidžil blagajskog kadije 1697.-1793., sheet 41/b.

65 N. LAšvanin, Ljetopis, p. 228. There is still a legend among the people about Diva Grabovčeva, a Catholic girl, who chose death rather than marriage to Tahir-bey Kopčić. https://cupdf.com/document/ciro-truhelka-djevojacki-grob. html (accessed: 10 May 2021). 
examples of marriage of a Muslim man and a Christian woman can be found, even though they did take place. Christian girls agreed to marry Muslim men for various reasons. Not every wedding, tough, was concluded with mutual consent. ${ }^{66}$ In the official letter he sent to the Bosnian Apostolic Vicar in 1755, Fr. Bono Benić said in one place: that there were so many "kidnapped girls whose marriages were conducted by Turkish judges (after their kidnappers used them as their own wives for many months, despite the opposition)". Benić further states that the Franciscans released girls in the courts from kidnappers, emphasizing that they did not sell but fiercely defended the holy sacraments. ${ }^{67}$

It was difficult for the girls to defend themselves from aggressive persons who, in addition to violence, were also blackmailing in order to pressure them into marriage. This was evidenced in the case of Anda Pilipović from Pijavice, which occurred in 1770. Anđa was first raped by the Muslims of Jajce, and then promised a "high-class marriage" if she would convert to Islam. The girl vehemently resisted pressure, because of which she was summoned before the pasha of Travnik. She was to explain the reasons for refusing to convert to Islam. Neither his threats nor his persuasions yielded results. Anđa escaped and took refuge in Sinj, which was the reason enough for the pasha to fine three parishes: Jajce, Dobretići and Kotor (Varoš). The parishes had to pay a total sum of 1,200 guruş. ${ }^{68}$ Muslim girls were not spa-

66 About forced marriage of Catholic girls to Muslims, as well as the Catholic marriages in Sharia court see: ANTE ŠKEGRO, "Katolici u mešćemi, šerijatska vjenčanja katolika: primjer župe Skopje u središnjoj Bosni" [The Sharia law marriages of Catholics in the parish of Skopje in Central Bosnia], in: Bosna franciscana, 22 (40), Sarajevo, 2014., pp. 139-202.

67 B. BENić, Ljetopis sutješkoga samostana, p. 196.

68 J. BALtić, Godišnjak od događaja..., p. 59. About kidnappings and forced conversions to Islam of Christian girls see: LuCıjA RADoš, "Prisilno poturčivanje katoličkih djevojaka u Bosni u prvoj polovini 18. stoljeća na primjeru manifesta katolika iz Jajca" [Forced conversions to Islam of Catholic girls in Bosnia in the first half of the $18^{\text {th }}$ century as exemplified in the manifest of Catholics from Jajce], in: JosıP GRUBEŠA (ed.), Rama-nekoć $i$ danas. Zbornik radova s Međunarodnoga znanstvenog skupa Prozor - Rama, 18.-19. lipnja 2009., Matica hrvatska, Prozor - Rama, 2010., pp. 63-78. Kidnappings of Christian girls and forced conversions to Islam were also recorded in the $19^{\text {th }}$ century. In 1829 , in addition to the great persecution of Christians in Bosnia, and the autocracy of local rulers, Baltić also records the abduction of Christian girls, but without giving specific examples. J. BALtıć, Godišnjak od događaja..., pp. 115-116. 
red from the attacks of various lustful men either. In 1789, Merjema Kuko from Kosor sued Ramadan Balalić, a villager, for attacking her with the intention of "committing an ugly act". She saved herself by shouting, and Ramadan escaped. ${ }^{69}$ The two examples above cannot be compared due to the nature and severity of the attack on Anda. From what has been presented in this paper so far, it is clear that such violence against Christian girls was much more common what can be found in the sources researched in the paper. The information about children born in these violent relationships is another thing that cannot be found. Given the violence and blackmail to which Christian girls were exposed, this was, most certainly, happening. However, only speculations about their lives and destinies are possible, because the information cannot be found within the sources. It can be stated that the children of Muslim fathers were also considered Muslims, and their fate was determined by the social status of their father, but also by the (non)acceptance of the Christian families in cases where the girls remained unmarried.

There are also no instances of custom of primae noctis recorded in the sources. This custom was used by aghas and beys to spend the night before the wedding with a bride to be. The custom is vividly remembered as the representative example of the injustices and violence the Christians, especially the girls, were exposed to. In order to avoid this practice, and to protect their brides, Christians often conducted group weddings. As many as 60 couples were known to get married in a single wedding ceremony. This way, only one bride would get hurt. The custom of group weddings remained in practice in some areas of Bosnia until the beginning of World War II. ${ }^{70}$

\section{The other side of the coin}

Despite murders, various conflicts and pressures, violence and ubiquitous insecurity, Christians and Muslims lived, worked to-

69 Sidžil blagajskog kadije 1760.-1835., sheet 17/a.

70 The information about the custom of primae noctis that was practiced not only in Europe, but in the lands that were part of the Ottoman Empire are brought by Marko Dragić. The information is based on the narratives of older people. Marko Dragić "Harač i drugi zločini u Mažuranićevom spjevu 'Smrt Smail-age Čengića' i suvremenom narodnome pripovijedanju" [Harač (taxes) and other crimes in the epic "The death of Smail-agha Čengić" by Ivan Mažuranić and in contemporary folk narrative], in: Milorad NikčEvić (ed.), Zbornik Ivan Mažuranić (1814-1890) i Crna Gora, HCDP "Croatica-Montenegrina" RH 
gether and cooperated. Throughout the $18^{\text {th }}$ century, examples can be found from which the positive and benevolent attitude of individuals towards reaya can be read. Regardless of the persistence of the perpetrators in procuring ways to unjustly accuse or humiliate reaya, there were always those who were willing to stand up for the poor. The Bishop of Makarska, Nikola Bianković (1645-1730) also wrote about this. After visiting the diocese of Duvno in 1710, he noted the benevolent attitude of the beys of Kopčić towards Christians. He also noted that the Kopčić brothers, rulers of Duvno at the time, had received him extremely friendly. ${ }^{71}$ Chroniclers also recorded cases of people who helped them and stood up for them in different situations, having remembered their kindness and sense justice. They often were rewarded for their services, but there were those who did not ask for or expect a "salary" of any kind. One of them was Bećiraga Meter Osmanagić, citizen of Sarajevo. Bećiraga advised the Franciscans throughout their efforts to obtain a ferman for the construction of the Kreševo monastery. He promised to do everything in order for the friars to get ferman "without asking for any personal benefit". ${ }^{72}$ There was also a müsellim (pasha's lieutenant) of the new pasha of Travnik (his name is not recorded) who neither took money from the Franciscans, nor wanted to commit violence against anyone. On the contrary, he punished and persecuted the Sarajevo and Travnik bashas who at that time (1750) were instilling fear in both Christians and Muslims. ${ }^{73}$ Hasan Effendi Nimčević is one of those chroniclers

\& CKD "Montenegro-Montenergina" u Osijeku \& Institut za crnogorski jezik i jezikoslovlje "Vojislav P. Nikčević" - Cetinje, Cetinje - Osijek, 2011, pp. 379-411; IDEM, "Povijesne i etiološke predaje o ljubuškom kraju" [Historical and etiological tales about Ljubuški province], in: Motrišta, 92, Mostar, 2016., pp. 43-49.

71 "Haec prae caeteris praestiterunt quator germani fratres Copcich quibus tantum baptisma ut inter fideles christianismi, sint videtur desiderari. Non solum enim quamcumque in ortodoxas viduas caeterosque pauperes incolas charitatem exercent, etiam apud turcica tribunalia, verum extraneos quoque christianos ac ipsos apostolicos visitatores hospitio excipiunt perquam benevole quotquot illo pervaniant.", BAZILIJE PANDžIć, "Izvještaji makarske biskupije sačuvani u Tajnom vatikanskom arhivu" [Reports of Diocese Makarska preserved in the Secret Vatican Archives], in: Nova et vetera, 30 (1), Sarajevo, 1980., p. 162.

72 M. Bogdanović, Ljetopis kreševskoga samostana, p. 58. Bećiraga later asked for 100 ducats for help in obtaining a permission to build a monastery, which were given to him by the Franciscans. Ibid., p. 79.

73 N. Lašvanin, Ljetopis, pp. 232-233. One of the chroniclers did not fail to mention the mubaşır who did not want to take extra money to inspect the mona- 
who also wrote in a beautiful light about. He was a representative of the Franciscans in Travnik and treated them kindly. ${ }^{74}$ There are also others whose names are not recorded in the chronicles, but who, using their position and knowledge, helped the Christians with whom they mingled and whom they befriended, sometimes rescuing them from a certain death.

In addition to dignitaries, the chroniclers also recorded names of those who had no such influence, but whose deeds and conduct testify to the human relationship with Christians during the times when being and remaining a human was the most difficult of tasks. We cite the example of Arslanbey Kovčić recorded in 1690. The aforementioned fulfilled a wish of a Christian boy on deathbed, who was hired to work for him and died of the plague. The boy begged Kovčić to bury him according to Christian customs, from the money earned while being hired. A stone cross was to be put on his grave and the celebration of High Mass was to be paid for. Kovčić went to the Franciscans and told them of the deceased boy's they were supposed to realize. The magnanimity of the deed is best witnessed by the chronicler himself who commented that many Christians did not fulfil the wishes of their dying ones, and there was a Muslim doing exactly that. ${ }^{75}$ It is clear that Kovčić did not have to fulfil boy's wishes. Nobody would ever find out about the words of the dying boy, nor would anyone have reason to criticise Kovčić had he not kept his word. But he chose differently, which speaks best about what kind of man Arslanbey Kovčić was and why his full name deserved to be recorded by the chronicler. In the chronicle of 1769, the name of another Muslim who stood out from most of the people of his religion by his conduct, was recorded by the chronicler. For years, the Franciscans had been trading with a certain Husein Gušter, a tanner from Sarajevo. They sold him hides every year because Husein, although poor, was not insidious and violent towards the Franciscans. He was gentle and honest in price. ${ }^{76}$

stery, although others did so without any hesitation. B. Benić, Ljetopis sutješkoga samostana, p. 165.

74 M. Bogdanović, Ljetopis kreševskoga samostana, p. 71; B. BENić, Ljetopis sutješkoga samostana, p. 232.

75 N. Lašvanin, Ljetopis, p. 198.

76 M. Bogdanović, Ljetopis kreševskoga samostana, p. 133. Not all merchants were like Husein. One of the chroniclers recorded in 1830 that a Sarajevo merchant wanted to sell sick cattle by force to the Fojnica guardian. When the 
Guarantees were another form of cooperation between Christians and Muslims. In the Ottoman period, individual or collective guarantees $^{77}$ were a way by which the authorities sought to ensure peace and security. Residents of one village or mahala would often provide guarantees for the residents of other. Guarantors were being sought in various litigation cases. Countless examples of members of one religious community representing or guaranteeing, in different situations, for their household members, neighbours, but also for members of other religious communities can be found across sicils. ${ }^{78}$ Thus, Muslims guaranteed for Christians and Christians guaranteed for Muslims, although the number of such examples was negligible. ${ }^{79}$

guardian refused, the merchant threatened to kill him. Later on, the same merchant came to the monastery and fraternized with the guardian. It is interesting how the chronicler commented on the merchant's action: "Turčin kad ne more ništa fratru oli krstjaninu učiniti, onda se pobrati. [When a Turk is not able of harming a friar or a Christian, then he fraternizes]." J. BALTić, Godišnjak od događaja..., pp. 118-119.

77 More about warranty see: Azra Gadžo-Kasumović, "Kolektivno i pojedinačno jamstvo, kefalet-defteri i registracije kefaleta u dokumentima u Bosni osmanskog perioda" [Collective and individual warranty, bail books and bail registrations in Bosnia of Ottoman period], in: Anali GHB, 35, Sarajevo, 2014., pp. 5-50.

78 Here we refer to pages / sheets listing examples of guarantees, as well as examples in which Muslims represent or guarantee for Christians in various lawsuits. Sidžil nevesinjskog kadije 1767.-1775., pp. 18, 21, 30, 33, 35-36; Sidžili mostarskog kadije, fragmenti iz 1044-1207. h. god. / 1635-1739., p. 100; Sidžil blagajskog kadije 1728.-1732., pp. 15, 45-47, 49-51, 62, 66, 83-84, 104; Sidžil mostarskog kadije, fragmenti iz 1179-1182. h.g. / 1765-1769., p. 11; Sidžil blagajskog kadije, fragmenti 1113.-1212. (1702.-1798.), sheets 9/b, 14/a, 18/b, 38/b, 46/a, 47/b, 58/a; Sidžil blagajskog suda, fragmenti iz 1183.-1201. (1769.-1787.), sheets 22/b, 24/b, 31/b, 41/a, 44/a, 50/b, 56/b; Sidžil blagajskog kadije 1760.-1835., sheets 1/a, 7/b, 13/b, 14/a, 28/a, 55/b, 75/b, 86/a, 86/b, 92/a, 92/b, 96/a, 96/b, 97/a; Sidžil blagajskog suda, fragmenti iz 1170.-1237. (1757.-1822.), sheets 24/b, 25/a; Sidžil blagajskog suda 1697.-1793., sheets 2/a, 7/b, 11/b, 15/a, 15/b, 16/a, 37/a, 38/b, 71/a; Sidžil blagajskog suda, fragmenti iz 1141.-1203. (1729.-1789.), sheets 19/a, 19/b, 23/b, 31/a, 34/a, 41/a, 47/b, 55/b, 84/a; Sidžil blagajskog kadije 1698.-1779., sheets 2/b, 32/a; B. Benić, Ljetopis sutješkoga samostana, p. 142.

79 In documents, we find only a few examples in which a Christian guarantees for a Muslim. In the village of Lokve, Ismail Bošnić and Jovan Lisica guaranteed for each other, as did Hasan Burmazić and Jovan Milašogli. Sidžil blagajskog kadije 1728.-1732., p. 66. In the village of Dabrica, for Osman, whose brothers were Muslims, Marić Vučjak had guaranteed. Sidžil blagajskog suda, fragmenti iz 1173.-1250. (1760.-1835.), sheet 7/b. 
Christians, as members of another religious community were in a subordinate position, so their voice did not have the same weight as the Muslim. Nevertheless, the examples that can be found it the sources show that Christians and Muslims in different situations sought and found support and help from each other. It is not known whether help was provided because there was no other choice, or for some other reason. It is not possible to conclude whether there was a blood connection or some other connection between them form the information in the source, but such a possibility cannot have ruled out either. The conversions to Islam lasted throughout the whole period of Ottoman rule. It is unknown to what extent and for how long the converts and their offspring remained connected with their Christian cousins. It is certain, though, that mutual contacts and connections of islamized relatives and their Christian cousins existed after the conversion to Islam took place.

Much can be learned from sicils about Christian-Muslim relations in the Ottoman period. Sicils also contain in addition to all kinds of information about violence and lawsuits, recorded information about the brighter side of life during the Ottoman period - weddings. Even though they do not contain examples of marriages of Muslim men and Christian women, the information about considerable number of Christian couples who married before the kadi are plenty. ${ }^{80} \mathrm{~A}$ certain number of couples took prominent Muslims, bearers of different titles, as representatives or witnesses at the wedding. ${ }^{81}$ It is impossible

80 Christians used to conduct Sharia weddings for different reasons. Some couples did it because their parents were opposing the marriage. Some couples did it because they were related, and some did it simply because they were careless. Some couples married in Sharia custom in cases of kidnappings or because of the fear of bride kidnapping by the Muslims. Sometimes, the Sharia marriage custom ceremony was done to save the bride from being coerced into marrying a Muslim. The Sharia wedding of Christians would earn them excommunication by the bishop. Many of the couples would eventually conduct a Christian wedding, after they would get absolution from the bishop. For more information of the causes of Sharia weddings of Christian couples see: A. ŠKEGRO, "Katolici u mešćemi, šerijatska vjenčanja katolika", pp. 149-165.

81 We find several examples in the sources in which the groom or the bride, sometimes even both, have persons with the title of basha, mulla, celebi or effendi as representatives or witnesses at the wedding. Sidžil nevesinjskog kadije 1767.-1775., p. 11; Sidžil blagajskog kadije 1728.-1732., p. 93; Sidžil blagajskog suda, fragmenti iz 1141.-11203. (1729.-1789.), sheet 30/a; Sidžil blagajskog kadije 1697.-1793., sheet 31/b; Regesta blagajskog suda, fragmenti iz 1124.-1243. (1712.-1827.), sheet 24/b; Regesta sidžila blagajskog suda, fragmenti iz 1183.- 
to distinguish whether the Muslim representatives were kin to the newlyweds, but the fact is that the proxy or a witness at the wedding was carefully chosen. These were usually close friends and respectable people, although it is possible that some of the representatives witnessed for a certain fee. More prominent Muslims could stand up for Christians because they had the power and opportunities to act, as members of the Ottoman ruling structure. This possibility was unattainable or denied to the Christians. Therefore, it was very important for Christians to have someone who could provide protection at a time when life often depended on such protection. No less important were Christian relationships with their Muslim neighbours, with whom they were socializing, working, helping them and receiving their help. Their relationships were often built and strengthened by children's godparents. The custom of so-called "first haircut godparenthood" was often practiced in Herzegovina. According to this custom, a haircut godparent (Muslim or Christian) would cut a lock of hair from a child with scissors and give an appropriate gift to the child. This way, the two families were not only permanently connected but existing friendships were also strengthened. ${ }^{82}$ Although Quran does not prescribe godparenthood, and therefore no obligation in this regard, the obligation of the haircut godparent was to protect and help not only the godchild, but also his parents. This sometimes meant the difference between life and death for Christians. Perhaps, owing to such a practice, the proverb: "Hey, Turk, godfather in the trouble!" was created. This plastically depicts the reality of a Christian subject under the Ottoman rule. Regardless of prejudices concerning folk proverbs, they were created and are being made in response to challenges of everyday life and carry a lot of truth in themselves. The date of origin of the proverb is unknown, as

1201. (1769.-1787.), sheet 55/b; Sidžil blagajskog kadije 1698.-1779., sheet 24/a; Sidžili mostarskog kadije, fragmenti iz 1044-1207. h. god. / 1635-1739., pp. 94, 95, 98-99; Sidžil mostarskog kadije, fragmenti iz 1179-1182. h. g. / 1765-1769., pp. 25, 129, 130, 131-132. Juvenile Muslim girls were married with the permission of a legal representative (veli), and "fair" witnesses had to be present at the wedding. Sidžil blagajskog suda, fragmenti iz 1170.-1237. (1757.-1822.), sheet 29/a. Since they were married at the Sharia court, the same was applied for Christian girls.

82 The custom of haircut godparenthood has been preserved in $\mathrm{BiH}$ to this day. The author of these lines had a lock of her hair cut by her godparent when she was a one-year-old child. Therefore, she is a living witness to the existence of the custom. 
Dijana Pinjuh - Relations between Christians and Muslims...

is the date of its recording, but we can say without hesitation that it can be applied to the entire period of the Ottoman rule in $\mathrm{BiH}$.

\section{Conclusion}

In order to create a comprehensive picture of life and Christian-Muslim relations, much more written evidence, than what was presented in this paper, is required. The sources researched in this paper provide only fragmented insight into history of everyday life, which for most Christians and Muslims was all but easy and simple. Numerous examples of various lawsuits in which Christians and Muslims sought satisfaction for the injustices inflicted on them are contained within sicils, while the chronicles provide much more details about the violence and injustices suffered by the Christians. Sicils were written by kadis, Ottoman officials who carried out the orders of their superiors and who acted according to an already established practice and well-established pattern. The authors of the chronicle wrote from their own personal experience, or of what they had been told of. The kadis recorded events because it was their job for which they were paid. The chroniclers wrote to save the memory of the events from oblivion. Both have left us valuable traces and benchmarks about the lives of Christians and Muslims in a period that, for many was and remained, a period of misfortune and suffering.

The attitude of the Ottoman authorities towards their subjects was largely determined by the political situation and the balance of forces on the battlefield, and numerous fines and levies further aggravated the position of the population. The initiators of violence were various outlaws, foreigners or members of the local governing structures. The behaviour of Muslim neighbours was often a reaction to the violence and harassment of powerful locals, who, under different pretexts, exploited both Christians and Muslims for the sake of their personal enrichment. The local Muslims often blamed Christians for their troubles, and that contributed to the deterioration of Christian-Muslim relations and mutual intolerance, in an instance where the subordinate position of one group and the superior position of another was evident. Using their position and the powers that position carried with it, many Muslims attacked, persecuted, or punished Christians, often without any appropriate reason. Even though Christians had an open and free access to the kadi and his justice, there were kadis who caused misfortunes and injustices that afflicting Christians. However, even then, there were individuals who pro- 
tected or helped Christians. We do not find many such examples in the sources, but their scarcity does not diminish the value and significance of what they did. Uncertainty of everyday life did not entirely destroy an understanding and empathy of the people for each other, nor did attacks and violence permanently disturb interpersonal relationships. The examples of mutual respect and help, people of different religions were providing each other, are the most vivid indicators of the way of life at that time. 